\title{
Identification of Extractives from Various Poplar Species
}

\author{
Dominika Szadkowska *(D), Janusz Zawadzki, Paweł Kozakiewicz (D) and Andrzej Radomski \\ Institute of Wood Sciences and Furniture, Warsaw University of Life Sciences in Warsaw-SGGW, \\ Nowoursynowska 166 Street, 02-787 Warsaw, Poland; janusz_zawadzki@sggw.edu.pl (J.Z.); \\ pawel_kozakiewicz@sggw.edu.pl (P.K.); andrzej_radomski@sggw.edu.pl (A.R.) \\ * Correspondence: dominika_szadkowska@sggw.edu.pl
}

Citation: Szadkowska, D.; Zawadzki,

J.; Kozakiewicz, P.; Radomski, A. Identification of Extractives from Various Poplar Species. Forests 2021, 12, 647. https://doi.org/10.3390/ f12050647

Academic Editor: Joana Ferreira

Received: 20 April 2021

Accepted: 16 May 2021

Published: 19 May 2021

Publisher's Note: MDPI stays neutral with regard to jurisdictional claims in published maps and institutional affiliations.

Copyright: (c) 2021 by the authors. Licensee MDPI, Basel, Switzerland. This article is an open access article distributed under the terms and conditions of the Creative Commons Attribution (CC BY) license (https:// creativecommons.org/licenses/by/ $4.0 /)$.

\begin{abstract}
Fast-growing poplar trees from plantations are the source of inexpensive wood that is intended mainly for chemical processing in the pulp and paper industry. Their potential as raw material for biofuel manufacturing is widely discussed as well. The detailed chemical composition of this raw material is therefore an important question. Five species of poplars were investigated: Populus alba, P. maximowiczii, P. trichocarpa, P. nigra, and P. tremula. Wood is a material consisting mainly of lignocellulose, but there are also many extractives. In temperate zone climate they typically represent up to $5 \%$ of wood mass. Their identification is difficult, due to various classes of compounds and great number of individual ones. These compounds can affect the properties of wood-its resistance to biotic agents and suitability to enzymatic treatment towards biofuels. Gas chromatography coupled with mass spectrometer (GC-MS) was used to analysis of extractives in various species of poplar wood. Compounds from several classes were identified like phenols, fatty acids, and their derivatives, sterols. Their identification was discussed along with estimation of their content in wood of investigated species.
\end{abstract}

Keywords: gas chromatography with mass spectrometry; poplar wood; wood extractives

\section{Introduction}

Trees of the genus Populus (poplars, aspens, cottonwoods and hybrids; hereafter: poplars) arewidely distributed species across land areas of temperate zone due to their tolerance for a broad range of environmental and soil conditions. Poplar species are characterized by rapid growth to very large size and high genetic variability. Poplar has economic feasibility for industrial products. Due to poplarsvariability, its wood maybe applied in a variety of industrial products. These are factors determining the recent fast development of poplar products and its future economic and environmental potential [1]. There are three native poplar species: European aspen (Populustremula L.), white poplar (Populus alba L.), and black poplar (Populus nigra L.) in Poland [2]. However, non-native species are also found in plantation for industrial purposes [3]. Similar trends can be observed around the world $[4,5]$.

One of the most important branches of industry that use wood as a raw material is energy production. While the most common way is still direct burning of wood, new Renewable Energy Directives (RED [6] and RED II [7]) promotes the use of energy from renewable sources, thus using wood as a source of liquid biofuels, like ethanol, is a topic of growing scientific interest [8-10]. The main source of bioethanol is cellulose, hydrolysed to glucose, which can be fermented by yeasts. Contemporary expectations limit hydrolysis to enzymatic processes as environmentally friendly. The main disadvantages of the use of enzymes are their cost and susceptibility to inhibitors, which are present in raw biomass or can be formed during its pretreatmeant [11-13].

Wood is a material made of lignocellulose. The main polysaccharide component is cellulose. Together with hemicelluloses, they are based on a lignin structure. Lignin is an aromatic polymer. Wood components are complemented by extractive and mineral substances $[14,15]$. The individual components of wood connect with each other; 
these connections are highly complicated due to the nature of the combined compoundshydrophilic polysaccharides and hydrophobic lignin [16].

Extractives are a diverse group of compounds that can be isolated from wood with the use solvents, including essential oils, fats, waxes, phenols, etc. Their content in wood ranges from 1 to $20 \%$, depending on the species $[16,17]$. Wood extractives affect many aspects of wood processing. They can influence its resistance to weathering and abiotic conditions [15]. Extractives change the color of wood and influence its durability, gluability, etc. [18]. They can affect enzymatic hydrolysis both as inhibitors and process catalysts depending on the composition, as well as on the way the effect is analyzed-the extract itself may have a different effect from individual components [19-21]. The aim of this work was to develop a method of extractives composition analysis in different poplar species Obtaining these results will allow to determine the influence of individual compounds on biochemical processes (such as enzymatic hydrolysis or alcoholic fermentation).

Individual substances used as potential inhibitors of enzymatic hydrolysis may inhibit it, but not always their mixture [22,23].

The aim of this work was to develop a method of extractives analysis and determination of their composition in various poplar species. Obtaining these results will allow to determine the influence of individual compounds on biochemical processes (such as enzymatic hydrolysis or alcoholic fermentation).

\section{Materials and Methods}

Wood of various poplar species (the names of wood according to EN 13556:2003 [24]) was obtained for the investigation. Origin (place of harvest-location) shown in Table 1 and Figure 1.

Table 1. Origin (location) of poplar trees used for research.

\begin{tabular}{|c|c|c|c|}
\hline Poplar Species & Age & Location * & Number of Specimen \\
\hline $\begin{array}{c}\text { Japanese poplar } \\
\text { (Populus maksimowiczi Henry) }\end{array}$ & 3,5 & $\begin{array}{l}52^{\circ} 08^{\prime} 42^{\prime \prime} \mathrm{N} \\
21^{\circ} 04^{\prime} 07^{\prime \prime} \mathrm{E}\end{array}$ & 4 \\
\hline $\begin{array}{c}\text { Black cottonwood (Populus trichocarpa } \\
\text { Torr. and A. Gray ex. Hook.) }\end{array}$ & 3,5 & $\begin{array}{l}52^{\circ} 08^{\prime} 42^{\prime \prime} \mathrm{N} \\
21^{\circ} 04^{\prime} 07^{\prime \prime} \mathrm{E}\end{array}$ & 4 \\
\hline European aspen (Populus tremula L.) & $\sim 40$ & $\begin{array}{l}52^{\circ} 37^{\prime} 40^{\prime \prime} \mathrm{N}, \\
22^{\circ} 51^{\prime} 11^{\prime \prime} \mathrm{E}\end{array}$ & 3 \\
\hline White poplar (Populus alba L.) & $\sim 60$ & $\begin{array}{l}52^{\circ} 18^{\prime} 50^{\prime \prime} \mathrm{N}, \\
19^{\circ} 04^{\prime} 53^{\prime \prime} \mathrm{E}\end{array}$ & 3 \\
\hline Black poplar (Populus nigra L.) & $\sim 60$ & $\begin{array}{l}52^{\circ} 09^{\prime} 41^{\prime \prime} \mathrm{N} \\
21^{\circ} 02^{\prime} 52^{\prime \prime} \mathrm{E}\end{array}$ & 2 \\
\hline
\end{tabular}

* Origin (place of harvest) shown in the Figure 1.

Wood of various poplar species was used to characterize the extractive content and their composition. The material obtained from each specimen ( 3 samples of about $100 \mathrm{~g}$ ) was crushed with Retsch SM100 laboratory mill andsieved.Chips fraction of $0.43 \div 1.02 \mathrm{~mm}$ were used for further analysis.

All the reagents used in the paper were obtained from Avantor (formerly POCh, Gliwice, Poland).

Wood chips fraction was extracted with azeotropic mixture chloroform: ethanol containing 7\% of ethanol [25]. Extraction was carried out for $10 \mathrm{~h}$ for every $5 \mathrm{~g}$ of woodchips placed in the thimble. After extraction, the solvent was evaporated and the flask was dried at $105{ }^{\circ} \mathrm{C}$. The content of extractives was determined in relation to the mass of absolute dry wood. Before chromatographic analysis samples were dissolved in $5 \mathrm{~cm}^{3}$ of methanol p.a. 


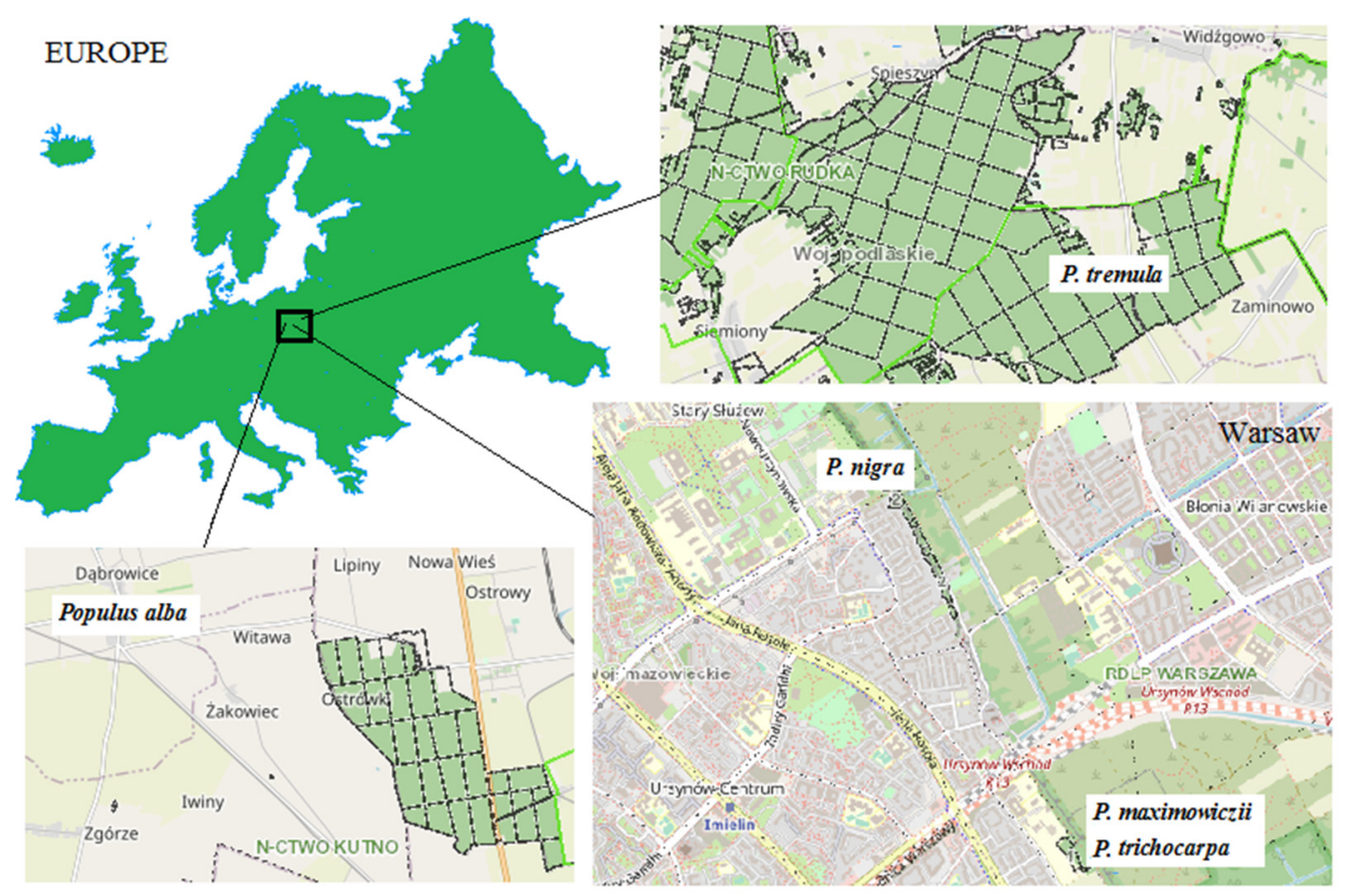

Figure 1. Origin (place of harvest) of poplar trees (https:/ / www.bdl.lasy.gov.pl/, accessed on 1 April 2021).

The analyses were carried out on chromatograph GC-2010 Plus coupled with mass spectrometer GCMS-QP2010 (Shimadzu, Kyoto, Japan); capillary column ZB-5MS with a length of $30 \mathrm{~m}$, a diameter of $0.25 \mathrm{~mm}$, and a bed of $0.25 \mu \mathrm{m}$ was used. The temperature program started at $50^{\circ} \mathrm{C}$ and was maintained for $7 \mathrm{~min}$, then the temperature was increased by $10{ }^{\circ} \mathrm{C} / \mathrm{min}$ to $320^{\circ} \mathrm{C}$ and then maintained for $10 \mathrm{~min}$. Helium 6.0 was used as the carrier gas, with the flow set at $0.8 \mathrm{~cm}^{3} / \mathrm{min}$. The samples were introduced directly on the column - the injection temperature was $250^{\circ} \mathrm{C}$ and the detector voltage was set to $1.2 \mathrm{kV}$. Samples were introduced to the column using the AOC-20i autosampler.

Obtained chromatograms were analyzed using dedicated GCMSsolution Version 2.72 software. A single run smoothing was applied using implemented Savitzky-Golay method at $2 \mathrm{~s}$ smoothing width.

Individual peaks were identified by comparing the spectrum with the NIST11, NIST11b spectrum library, while spectrum processing mode was set as "Peak top spectrum" in the case of raw spectrum and "Calculated form peak: in the case of background spectrum. The most probable matches were verified on the basis of literature data on the occurrence of individual compounds in plants, including woody plants, especially different poplar species, as described in detail below.

Due to variable slope and drift of baseline, no automated integration was applied. Manual integration was applied instead, using "Link point" method in the case of fully resolved peaks or "New baseline" - allowing vertical peak splitting in the other cases. Quantitative determination was performed manually on the base of peak areas and external standard calibration. The calibration curve was obtained at the same conditions for standard solutions of vanillin, corresponding to the content at 5 to $5000 \mathrm{mg} / \mathrm{kg}$ range. No correction for detector sensitivity was applied.

\section{Results and Discussion}

\subsection{Extractives Content}

The content of extractives (Table 1) was determined in the mixture of chloroform: ethanol (POCH, Gliwice, Poland) by mass ratio of 93:7. This mixture has been applied in order to eliminate solvent containing carcinogenic benzene. The selection of the mixture was made on the base of Hansen's three-component solubility parameter system [26] and verified as comparable with standard ethanol-benzene solvent [25]. The difference 
in the amount of extractives in relation to the literature data may result from the use of chloroform-ethanol mixture instead of classic solvents, as well as from different ages of some of the poplar varieties used. The smallest difference was observed for P. maximowiczii and the largest for P. nigra. The extractives content values for different poplars, with the exception of $P$. trichocarpa, reach similar values in Table 2.

Table 2. Extractives content.

\begin{tabular}{|c|c|c|}
\hline Poplar Species & $\begin{array}{l}\text { Extractives Content } \\
{[\% \pm \mathrm{SD}]}\end{array}$ & $\begin{array}{c}\text { Ethanol-Benzene Extractives } \\
\text { [\%] [Ref.] }\end{array}$ \\
\hline $\begin{array}{l}\text { Japanese poplar (Populus } \\
\text { maksimowiczi Henry) }\end{array}$ & $2.4 \pm 0.2$ & 2 [15], 3 [27], 2 [28] \\
\hline $\begin{array}{c}\text { Black cottonwood (Populus trichocarpa } \\
\text { Torr. and A. Gray ex. Hook.) }\end{array}$ & $0.9 \pm 0.1$ & $3[15], 3$ [27] \\
\hline European aspen (Populus tremula L.) & $2.7 \pm 0.2$ & $3.1[28], 2.0$ [29], \\
\hline White poplar (Populus alba L.) & $2.3 \pm 0.1$ & $\begin{array}{c}5[15], 5[27], 5.7[28] \\
5.7[30]\end{array}$ \\
\hline Black poplar (Populus nigra L.) & $2.0 \pm 0.1$ & $\begin{array}{l}5[15], 5[27], 2.1[28] \\
1.8[30]\end{array}$ \\
\hline
\end{tabular}

Chromatograms presented in Figure 2 indicate clear differences between the species studied. The highest number of peaks, simultaneously with the highest relative intensity, were identified in the wood extract of white poplar, outside the range of retention times above $33 \mathrm{~min}$. In this range, associated with the presence of mainly sterols and other terpenoids, as described below, white poplar wood extract contained the least compounds.

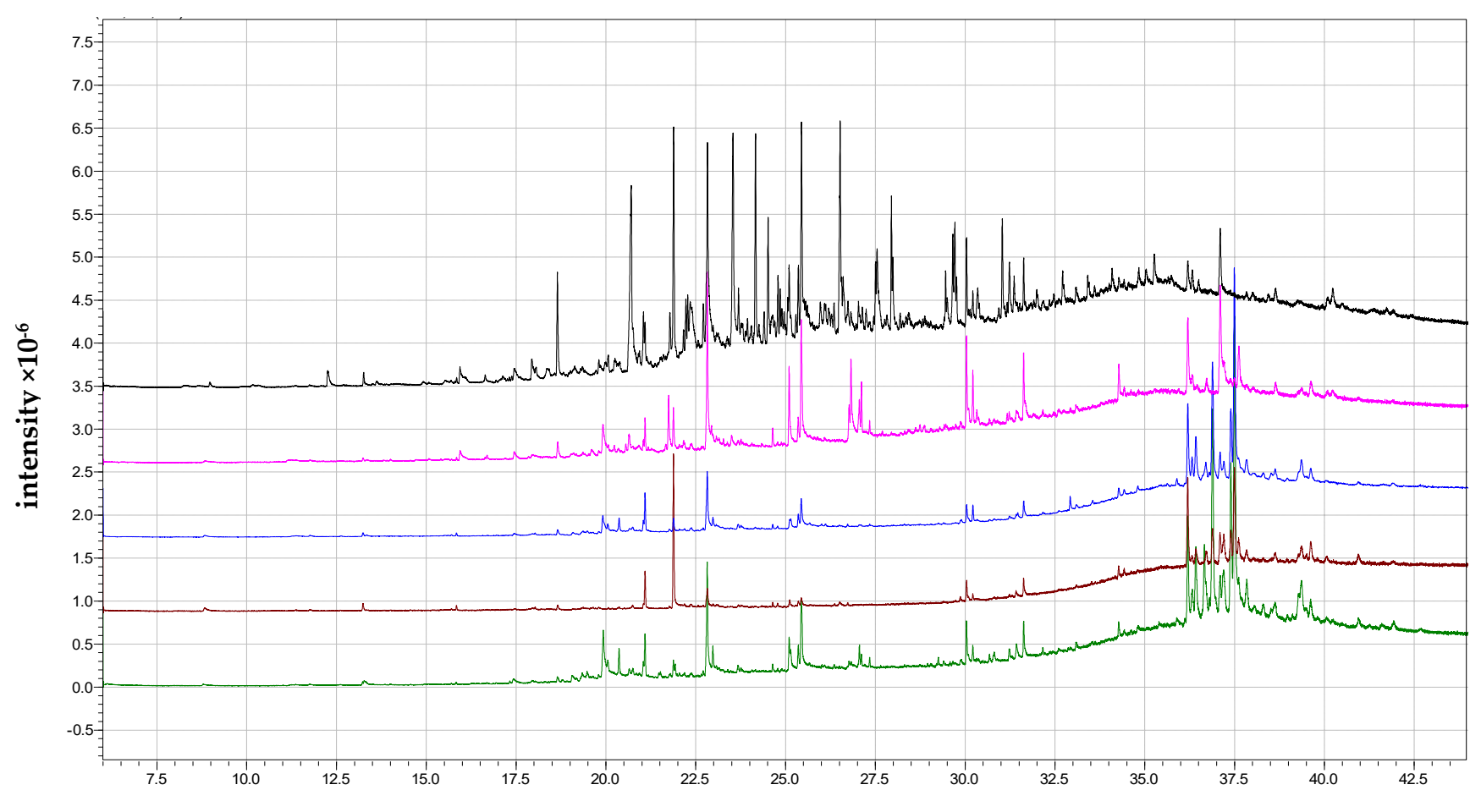

retention time/min.

Figure 2. Raw chromatograms of individual poplar samples (black—P. alba L., pink-P. tremula L., blue-P. nigra L., brown-P. trichocarpa Torr. and A. Gray ex. Hook., green-P. maksimowiczi Henry. 
Peaks were found to be present on all the chromatograms, as well as those found on some or even characteristic of only one extract. The separation of the substances on the chromatograms is sufficient to allow identification of the substances in the individual extracts. The compounds were best identified on European aspen chromatogram (Figure 3). The results of analyses were grouped into classes of compounds and discussed in the order of growing retention times.

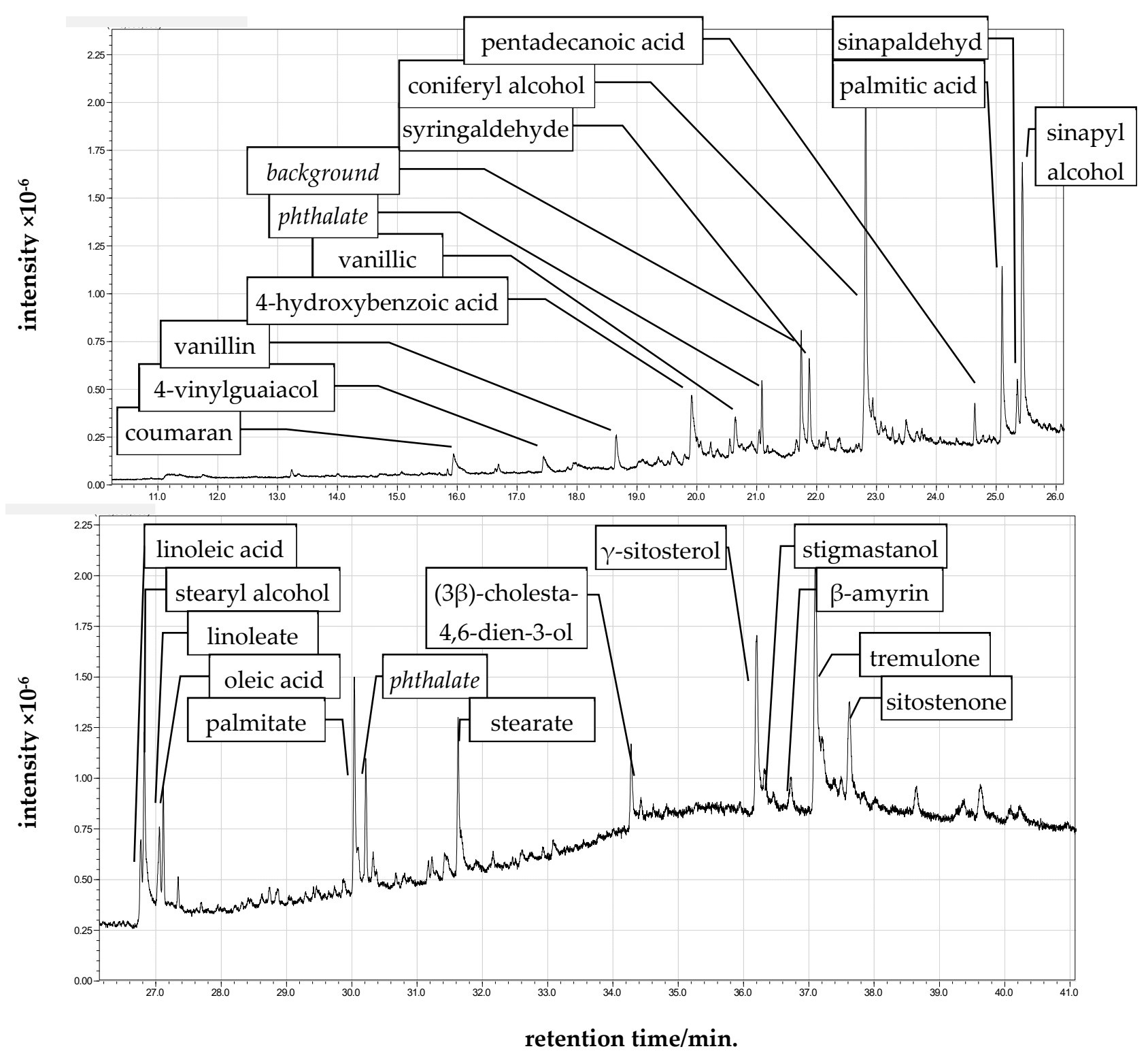

Figure 3. European aspen chromatogram (P. tremula L.) with peak identification.

\subsection{Phenols}

Table 3 presents phenolic compounds identified in wood extracts of five studied poplar species. 
Table 3. Phenolic compounds identified in wood extracts of the studied poplar species.

\begin{tabular}{|c|c|c|c|c|c|c|}
\hline \multirow{2}{*}{ Name } & \multirow{2}{*}{ RT [min] } & \multicolumn{5}{|c|}{ Content in Wood [mg/kg] (SD) } \\
\hline & & P. maximowiczii & P. trichocarpa & P. tremula & P. alba & P. nigra \\
\hline 4-vinylguaiacol & 17.43 & $108(10)$ & - & $278(26)$ & - & $5(1)$ \\
\hline vanillin & 18.66 & $47(5)$ & $44(6)$ & $328(21)$ & 997 (77) & $80(10)$ \\
\hline 4-hydroxybenzoic acid & 19.91 & $622(60)$ & - & $922(90)$ & - & $322(28)$ \\
\hline vanillic acid & 20.65 & $117(17)$ & - & $354(39)$ & $3024(195)$ & - \\
\hline syringaldehyde & 21.87 & 205 (19) & $261(19)$ & $644(56)$ & $1486(91)$ & $136(17)$ \\
\hline coniferyl alcohol & 22.83 & $1209(109)$ & $248(21)$ & $3196(227)$ & $550(48)$ & $810(76)$ \\
\hline syringic acid & 23.52 & - & - & - & $1304(134)$ & - \\
\hline acetosyringone & 23.96 & - & - & - & 190 (17) & - \\
\hline ethyl vanillate & 24.17 & - & - & - & $2192(148)$ & - \\
\hline $\begin{array}{l}\text { (3,5-dimethoxy-4- } \\
\text { hydroxyphenyl)acetic } \\
\text { acid }\end{array}$ & 24.41 & - & - & - & $221(17)$ & - \\
\hline protocatechuic acid & 24.51 & - & - & - & $741(79)$ & - \\
\hline sinapaldehyde & 25.35 & $161(15)$ & $54(4)$ & $373(35)$ & $111(8)$ & $118(8)$ \\
\hline sinapyl alcohol & 25.44 & $626(40)$ & $68(11)$ & $2542(155)$ & $751(69)$ & $254(22)$ \\
\hline acetosyringic acid & 26.51 & - & - & - & $1146(90)$ & - \\
\hline
\end{tabular}

2-methoxy-4-vinylphenol (4-vinylguaiacol) is a compound known primarily as a flavoring agent, in its natural state co-responsible for buckwheat odor. In wood, it is usually is associated with thermal modification [31] and pyrolysis processes. It was detected repeatedly in hardwood smoke $[32,33]$. Its presence was confirmed in bio-oil obtained by pyrolysis of genetically modified poplar varieties [34,35]. Zarzyński [36] confirms the occurrence of an isomeric compound-2-methoxy-6-vinylphenol-in the wood of, among others, European aspen (Populustremula) and brittle willow (Salix fragilis), but the author's identification may be questionable as he does not state which library he used and the compound does not appear in the most widely used NIST database.

Vanillin is one of the most commonly occurring phenolic substances in wood [37], which is confirmed by its identification in all studied poplar species, with the highest content of this compound found in the wood of white poplar (Populus alba). The compound is also a typical component of hydrolytic liquids formed by pretreatment of poplar wood [38,39]. Cantarella et al. [23] studied the effect of vanillin released from poplar wood by steam explosion treatment on hydrolytic enzyme activity and found that for a concentration of $0.5 \mathrm{~g} / \mathrm{dm} 3$, the effect was insignificant. They also did not observe synergistic effects with compounds such as acetic acid, furfural, hydroxymethylfurfural, syringaldehyde and 4-hydroxybenzaldehyde. On the other hand, Li et al. [40] found reversible inactivation of cellulase in the presence of higher amounts of vanillin (IC50 for $30 \mathrm{~g} / \mathrm{dm}^{3}$ ).

4-hydroxybenzoic acid is the simplest of the phenolic acids, found in abundance in Japanese and black poplar wood and absent in detectable concentrations in extracts from California and white poplar. It was confirmed as a fermentation inhibitor found in poplar wood subjected to steam explosion [41]. It is also one of the primary products of lignin oxidation of various poplar clones [42]. It is a substance with relatively low toxicity-the LD50 in mice (oral) is as high as $2200 \mathrm{mg} / \mathrm{kg}$ [43].

Vanillic acid is a derivative of vanillin that occurs in abundance in white poplar wood and in smaller amounts in Japanese poplar and aspen wood. Reports of its presence in oak, cherry or acacia wood are available in the literature [44], and it isidentified as a potential fermentation inhibitor present in the wood of poplar hybrids [45]. Interestingly, it is the main phenolic substance present in argan oil [46]. 
Syringaldehyde is one of the most common phenolic compounds found in wood [37] and also one of the oldest recognized [47]. At the same time, it is one of the main products of wood hydrolysis during hydrothermal treatment [48], in particular steam explosion treatment of poplar wood [23], with no significant effect on hydrolytic enzyme activity found for concentrations of $0.5 \mathrm{~g} / \mathrm{dm}^{3}$. It has been analyzed in genetic modification studies of poplars $[49,50]$, where its content in wood extracts is increased. The compound is considered to be an attractant for the woodworm Scolytusmultistriatus [51], attacking primarily elm, but also oak and aspen, among others.

Coniferyl alcohol is, apart from sinapyl and p-coumaryl alcohol, the primary precursor of lignin in the wood of both coniferous and deciduous species [52,53]. It is therefore not surprising that it is present in all the extracts examined, with only the white poplar (P. alba) wood extract not being one of the dominant peaks. Coniferol is also one of the primary compounds of interest in breeding poplar varieties, including genetically modified ones $[50,54,55]$. It is also identified as one of the phenolic inhibitors of enzymatic hydrolysis [13].

Syringic acid is a derivative of syringaldehyde that occurs as a dominant peak in white poplar extract and is undetectable in other species. The compound was identified as a potential fermentation inhibitor in poplar hybrid studies [45] andwas also detected in other types of lignocellulosic biomass-wheat straw, rice, and corn [56].

Acetosyringon is another syringaldehyde derivative that, like syringic acid, is found only in white poplar extract and is undetectable in other species. It has been linked to the plant stress response to wounding [57], which may be an alternative explanation for the presence of the compound in only one wood species.

Ethyl vanillinateis a derivative of vanillin and vanillic acid, identified only in white poplar wood. Since significant amounts of vanillic acid were also detected in this material, it is reasonable to believe that it may have been the source of the identified ester-formed during extraction with ethanol as the main solvent.

3,5-dimethoxy-4-hydroxyphenylacetic acid is an uncommon compound that is a homologue of syringic acid, with a longer alkyl fragment but shorter than in the phenylpropane unit. It is found in small amounts only in the wood of white poplar. There are reports of detection of this compound in volatiles (VOCs) present in thermally modified wood [31]. It is confirmed to be present in significant amounts in another lignocellulosic material considered as an energy source: tobacco stems [58].

Protocatechuic acid (3,4-dihydroxybenzoic acid) is one of the simplest phenolic acids that is found in abundance in numerous herbs (including rutabaga or mallow) [59]. In the extracts studied, it was detected only in white poplar. Tanase et al. [60] report the detection of significant amounts of this compound in the bark of various species of eucalyptus, as well as black spruce. It is also found in leachate obtained from hydrothermal treatment of wood [48]. Protocatechuic acid can be formed by biosynthetic processes from, among others: vanillic acid under the action of the enzyme vanillin monooxygenase (demethylase) [61] and p-hydroxybenzoic acid under the action of the enzyme 3-monooxygenase 4 hydroxybenzoate [62]. The presence of a large amount of vanillic acid in white poplar wood and the concomitant absence of a detectable amount of p-hydroxybenzoic acid points to the first pathway as a potential source of this compound. This is confirmed by the absence of protocatechuic acid in other poplar species, in which the vanillic acid content is much lower or undetectable.

Sinapaldehydeis a homologue of syringaldehyde, based on a phenylpropane skeleton, commonly found in phenolic wood [37]. It was found in a methanolic extract from the wood of quaking aspen, P. termuloides [63]. It was intensively studied as a marker for genetic changes in various poplar hybrids $[64,65]$. It was also detected alongside syringaldehyde in leachate after hydrothermal treatment of wood [48]. It occurred in every extract tested, although only in Japanese poplar in high amounts.

The sinapyl alcohol has not been identified by the library of MS spectra (Figure 4) used, which indicated 2,5-dimethoxybenzyl acetate or 3-(dimethoxyphenyl)-1-propanol as the 
most likely spectra. However, the query in the database did not show the presence of the mass spectrum of sinapyl alcohol in the library. At the same time, this compound was found in all the samples tested, as one of the dominating peaks in the chromatograms. Detailed analysis of the spectrum indicated the possibility of interpreting the main spectrum peaks in decreasing $\mathrm{m} / \mathrm{z}$ order (Figure 5 ):

210-molecular ion of sinapyl alcohol, $\mathrm{C}_{11} \mathrm{H}_{14} \mathrm{O}_{4}{ }^{+}$,

182-ethyl-syringol cation, loss of the $\mathrm{CO}$ fragment,

167-methylenesyringol cation, loss of $\mathrm{CH}_{2} \mathrm{CHO}$ fragment

154-syringol cation, loss of $\mathrm{C}_{3} \mathrm{H}_{4} \mathrm{O}$ fragment.

This interpretation is also given by Takahashi [66], so the identification can be considered as confirmed. Sinapyl alcohol is one of the main monolignols, i.e., precursors of lignin [67]. It is also one of the basic compounds tested in genetically modified poplar hybrids [50]. It has cellulase inhibiting properties $[68,69]$. On the other hand, there are reports of its catalytic effect on lignin degradation [70].

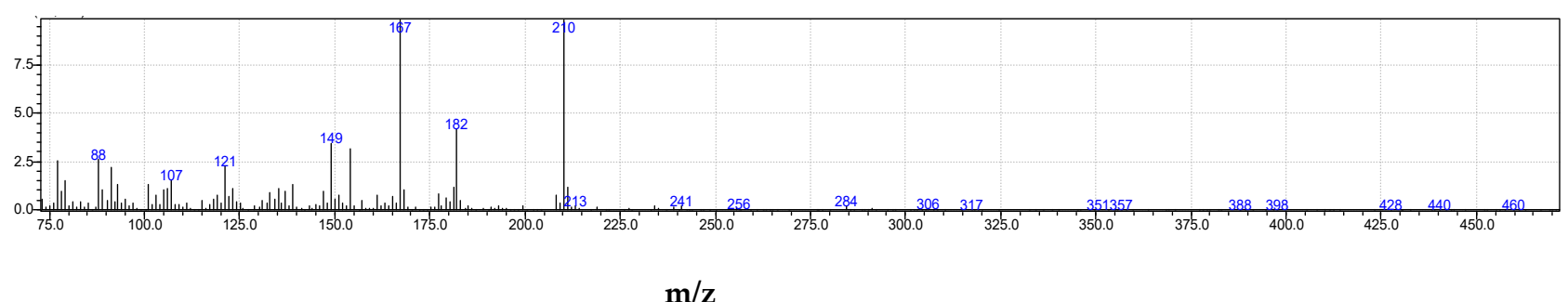

Figure 4. Mass spectrum of a compound identified as sinapyl alcohol.

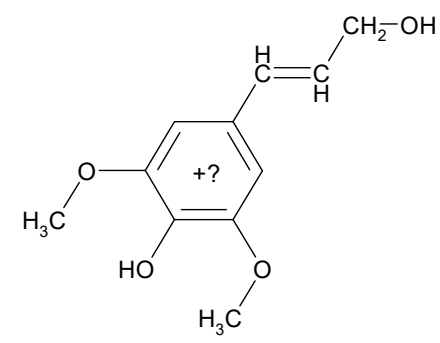

$\mathrm{m} / \mathrm{z} 210$

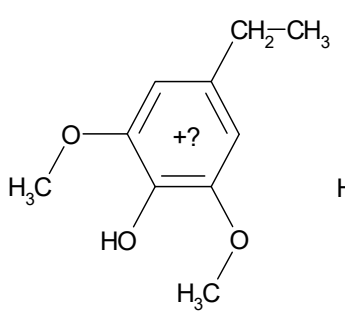

$\mathrm{m} / \mathrm{z} 182$<smiles>COc1cc(C)cc(OC)c1O</smiles>

$\mathrm{m} / \mathrm{z} 167$

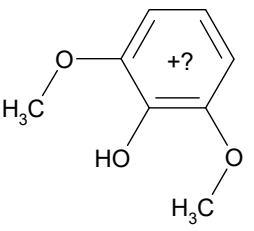

$\mathrm{m} / \mathrm{z} 154$

Figure 5. Presumed fragmentationof sinapyl alcohol.

The acetosyringic acid has (Figure 6) not been fully identified by the used MS spectral library. The MS spectrum shows significant similarity to syringic acid and lesser similarity to acetosyringone, but has an intense band corresponding to $\mathrm{m} / \mathrm{z} 256$. This may correspond to acetosyringic acid or be the result of fragmentation of an even larger molecule in which the hydroxyl group of syringic acid occurs as an ester. Ralph and $\mathrm{Lu}$ [71] reported that the acetylation of syringic compounds in position 4 may be the result of biological processes and that such groups are often found in the lignin of deciduous trees and dicotyledons. Structural units of lignin may also occur in the form of coumaric acid esters [72]. For willow and aspen wood, the hydroxyl group in position 4 often occurs in the form of p-hydroxybenzoate [71]. This type of ester linkage is also known to occur in tanninsdigallicand trigallic acids are known [73]. 


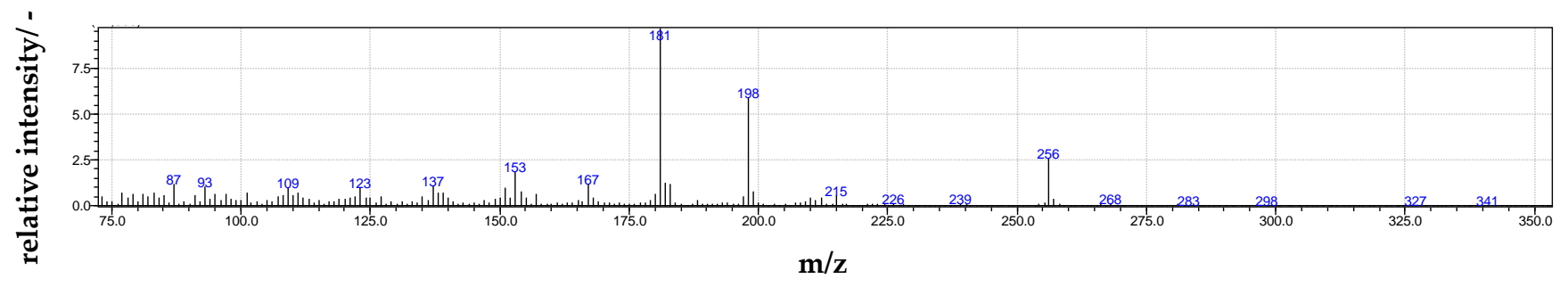

Figure 6. Mass spectrum of the compound identified as probably syringic acid acetate.

\subsection{Other Compounds Corresponding to Lignin Structure}

In addition to the classical phenolic compounds found in wood, three that are not obvious in terms of their presence in wood were also identified (Table 4).

Table 4. Other compounds identified in wood extracts of the poplar species tested.

\begin{tabular}{ccccccc}
\hline Name & RT [min] & \multicolumn{5}{c}{ Content in Wood [mg/kg] } \\
\hline & & P. maximowiczii & P. trichocarpa & P. tremula & P. alba & P. nigra \\
\hline coumaran & 15.94 & - & - & $365(33)$ & - & - \\
\hline 3,5-dimetoxyacetophenone & 20.74 & - & $48(4)$ & - & - & - \\
\hline olivetol & 22.98 & $146(10)$ & - & - & - & $78(7)$ \\
\hline
\end{tabular}

The coumaran unit is considered to be a typical lignin fragment of deciduous trees [74,75]. There are also reports of identification of coumaran as a chemical compound in wood [36], but it was identified in iroko (Chlorophoraexcelsa Benth. and Hook). The identification of coumaran in P. tremula raises the suspicion that it may also be a compound not found in the MS spectrum base used, with a larger molecule containing coumaran structure. On the other hand, a short retention time is an argument in favour of volatile compound with small molecules.

3,5-dimethoxyacetophenone is based on the skeleton of phenylpropane, but unusual because of lack of hydroxyl group in position 4. It occurs only in the wood of P.trichocarpa. There are reports of its identification in thermal treated poplar wood [31].

Identification of olivetol is uncertain. Olivetol is a compound known to occur in different lichen species [76] but is best known as a precursor of tetrahydrocannabinol (THC), found in Cannabis sativa $[77,78]$. Perhaps the compound found in P. nigra and $P$. maximowiczi is another phenolic compound not found in NIST libraries. One of the rare connections between poplar and olivetol is the work of Gange et al. [79], which identified 12 DABB-type proteins with a sequence similar to the enzyme olivic acid cyclase.

\subsection{Sterols and Terpenoids}

Another group of compounds present in wood extracts of the examined poplar species are sterols, and terpenoids derived from them (Table 5). These compounds have a structure based on the triterpene skeleton, differing in the location of double bonds and the type and distribution of functional groups. More than 200 phytosterols, i.e., compounds of plant origin, are known [80]. The identification of most of them is uncertain due to the little characteristic MS spectra, typical for hydrocarbon fragmentation. These compounds are not considered as enzymatic hydrolysis or fermentation inhibitors, nor are they generally considered to be toxic [81]. There are only reports of potential adverse effects of sterols on the endocrine management of vertebrates, especially fish $[82,83]$. Therefore, a detailed analysis of the correctness of identification is not appropriate for the purpose of this paper. Table 4 shows compounds which identification was based only on correlation with the MS spectrum base. The highest content and diversity of these compounds was stated for the wood of Japanese poplar, and the lowest for white poplar, in the extract of which only 
the presence of tremulone was detected, which was at the same time the only compound detected in all samples. The most frequently identified and present in the highest amounts were $\gamma$-sitosterol, stigmastanol, $\alpha$ and $\beta$-amyrin, $\alpha$ and $\beta$-amyrenone, and stigmastenone.

Table 5. Sterols and terpenoids identified in wood extracts from tested poplar species.

\begin{tabular}{|c|c|c|c|c|c|c|}
\hline \multirow{2}{*}{ Name } & \multirow{2}{*}{ RT [min] } & \multicolumn{5}{|c|}{ Content in Wood [mg/kg] } \\
\hline & & P. maximowiczii & P. trichocarpa & P. tremula & P. alba & P. nigra \\
\hline$(3 \beta)$-cholesta-4,6-dien-3-ol & 34.28 & - & $125(10)$ & $859(86)$ & - & 198 (18) \\
\hline$\beta$-sitosterol & 34.43 & - & $52(5)$ & - & - & $75(5)$ \\
\hline$\gamma$-sitosterol & 36.19 & $1151(111)$ & $997(102)$ & $1847(176)$ & - & $1093(74)$ \\
\hline stigmastanol & 36.32 & 847 (61) & $126(10)$ & $599(42)$ & - & $353(33)$ \\
\hline$\beta$-amyrenone & 36.42 & $801(72)$ & $248(24)$ & - & - & $739(63)$ \\
\hline$\beta$-amyrin & 36.70 & - & $161(15)$ & $314(30)$ & - & 357 (19) \\
\hline$\alpha$-amyrenone & 36.89() & $2001(208)$ & $479(37)$ & - & - & $1647(125)$ \\
\hline cholesta-3,5-dien-7-one & 37.10() & - & $364(28)$ & - & - & $361(33)$ \\
\hline $\begin{array}{l}\text { tremulone(stigmasta-3,5-dien- } \\
\text { 7-on) }\end{array}$ & 37.12() & $131(17)$ & $464(38)$ & $2930(277)$ & $180(19)$ & - \\
\hline$\alpha$-amyrin & 37.19() & $424(32)$ & - & - & - & 318 (17) \\
\hline 24-methylenecycloartanol & 37.40() & $476(33)$ & $362(33)$ & - & - & $884(54)$ \\
\hline $\begin{array}{c}\text { sitostenone } \\
\text { (stigmast-4-en-3-one) }\end{array}$ & 37.51() & $2411(230)$ & $1097(76)$ & - & - & $2832(274)$ \\
\hline (5 $\alpha)$-stigmastano-3,6-dione & 38.70() & $866(78)$ & $221(13)$ & - & - & $160(13)$ \\
\hline lupan-3-ol & 39.62() & $178(12)$ & $302(27)$ & - & - & - \\
\hline 9,19-cyklolanostan-3-ol & 39.63() & - & - & - & - & $149(10)$ \\
\hline
\end{tabular}

\subsection{Fatty Compounds}

Numerous fatty compounds were detected on the chromatograms of the examined extracts. In the absence of standards, their identification could only be based on the degree of similarity to the MS spectra present in the base used. However, it should be stressed that the spectra of fatty acids are not very common and often the identification is based on the presence of the mother peak [84]. Moreover, fatty acids are difficult to evaporate and their quantitative analysis is carried out after derivatization $[85,86]$. For this reason, the exact interpretation of the compounds in this group was not carried out, especially as they are not considered to be enzymatic hydrolysis inhibitors due to their difficult solubility in water.

In the extracts studied, compounds which most probable interpretation indicated free fatty acids, methyl or ethyl esters, which may have resulted from interaction with the solvent, as well as monoglycerides, were detected. The absence of di- and triglycerides on the chromatograms is due to their very low volatility, which prevents separation by gas chromatography.

The compound most frequently identified and giving the strongest signals on chromatograms was saturated palmitic acid $\mathrm{CH}_{3}-\left(\mathrm{CH}_{2}\right)_{14}-\mathrm{COOH}$, found in extracts from all wood species. Another acid is saturated stearic acid $\mathrm{CH}_{3}-\left(\mathrm{CH}_{2}\right)_{16}-\mathrm{COOH}$, also present in all samples, although large quantities were detected only in P. maksimowiczi. The next two acids: oleic $\mathrm{CH}_{3}-\left(\mathrm{CH}_{2}\right)_{7}-\mathrm{CH}=\mathrm{CH}-\left(\mathrm{CH}_{2}\right)_{7}-\mathrm{COOH}$ and linoleic $\mathrm{CH}_{3}-\left(\mathrm{CH}_{2}\right)_{4}-\mathrm{CH}=\mathrm{CH}-$ $\mathrm{CH}_{2}-\mathrm{CH}=\mathrm{CH}-\left(\mathrm{CH}_{2}\right)_{7}-\mathrm{COOH}$ were present in noticeable amounts only in P. trichocapra and P. tremula. Moreover, small amounts of lauric acid were detected in P. tremula and pentadecanoic acid in P. alba. In turn, the wood of P. nigra was probably found to contain stearyl alcohol. 


\subsection{Other Compounds with Difficult Identification}

In addition to the identified compounds, numerous peaks were detected in the samples which could not be identified, most often due to their too low intensity, making it impossible to eliminate the background effect and obtain MS spectrum in a quality allowing for comparison with the base. In some cases identification is impossible despite the presence of large peaks, because not all compounds present on the chromatograms are in the used MS spectrum library. Another possibility is the incomplete separation of the compounds, as exemplified by the small peak with a retention time of 26.82, occurring only on the chromatogram of $P$. tremula extract. Analysis of the MS spectrum did not bring any results. The comparison of the MS spectra determined for the initial and final peak fragment showed significant differences (Figures 7 and 8 ). The spectrum of the initial part of the peak resembles synapyl alcohol identified slightly earlier, while the spectrum of the final part of the peak is not very typical, however, there are groups of signals, which in combination with the $\mathrm{m} / \mathrm{z}$ difference of 14 (fragment $-\mathrm{CH}_{2}-$ ) are typical for hydrocarbon chains. This means that it is most likely that there is a mixture of some complex phenol and a fatty compound at this point in the chromatogram. Identification of components is not possible in this case without changing the conditions of the chromatographic analysis. Considering the complexity of the chromatogram, it can be assumed that changing the temperature program, which was the only way of working, would not give satisfactory results. The use of a chromatographic column with a different stationary phase, interacting differently with compounds of different polarity, would probably be the only appropriate method. However, there is no certainty that even then separation would be possible. No further research was carried out in this direction, but the example described is given because it illustrates well the complexity of extractive substance analysis.

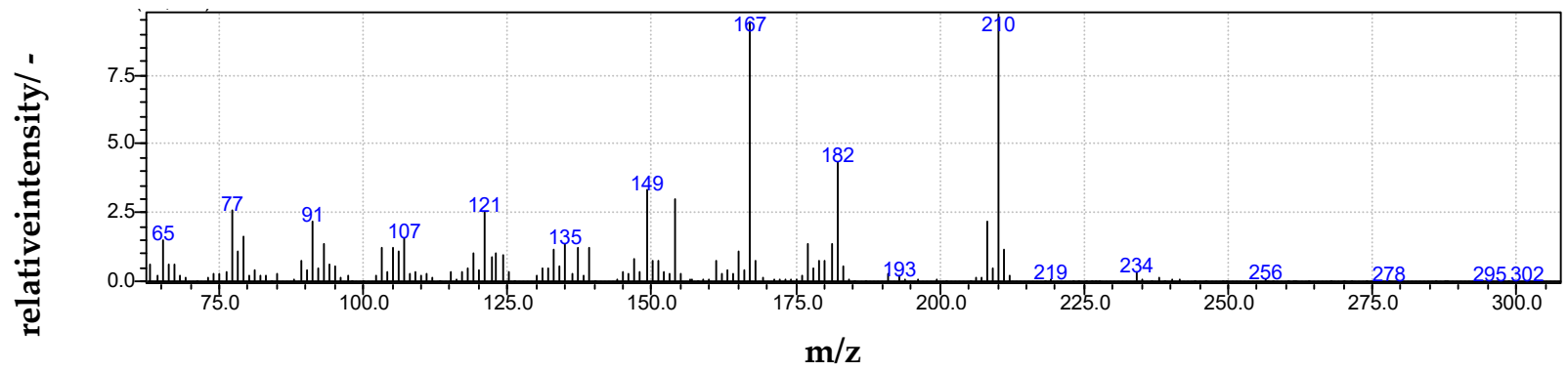

Figure 7. Mass spectrum of the initial unidentified peak fragment on the chromatogram of P.tremula extract with a retention time of 26.82 .

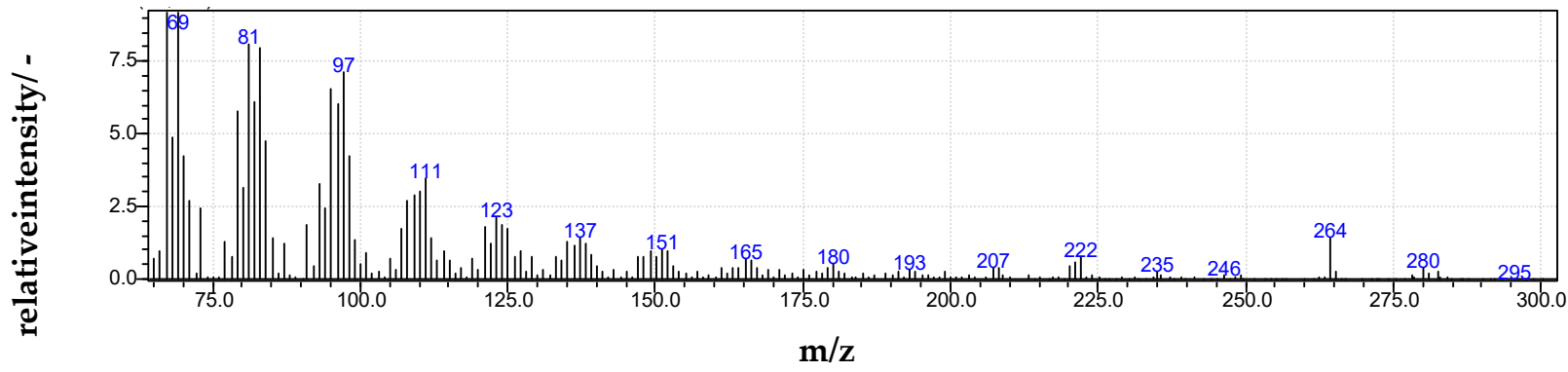

Figure 8. Mass spectrum of the final unidentified peak fragment on the chromatogram of P.tremula extract with a retention time of 26.82 .

A separate issue is the detection of compounds identified as phthalates in some extracts. One of them was detected in samples of $P$. trichocarpa and P. tremula, and two more in each separately. Such compounds do not occur naturally in wood, but are commonly detected in a variety of materials, including biological origin [87]. The cause is 
the contamination of samples with phthalates most often present in materials used for packaging $[88,89]$.

\section{Conclusions}

The aim of the study was the qualitative and quantitative analysis of the composition of extractives in wood of various poplar species from the viewpoint of the potential impact on the rate and efficiency of enzymatic hydrolysis of polysaccharides contained in wood. It was found that individual poplar species differ significantly not only in content, but also in the composition of extractives. Only a few phenolic compounds have been detected in wood of all species-vanillin, coniferyl, and sinapyl alcohols, syringaldehyde and sinapaldehyde. 4-vinylguaiacol, 4-hydroxybenzoic acid, and vanillic acid were detected in three species, while the remaining compounds were found only in the wood of white poplar. There was no correlation between the number of compounds detected and the total content of extractives.

Three uncommon compounds corresponding to the structure of lignin were detected, of which olivetol is widely known as a component of lichen species and Cannabis sp. herbs.

Significant amounts of sterols and other terpenoids have been found in the wood of the studied poplars. Contrary to phenolic compounds, the least terpenoids were found in the wood of white poplar, while the highest content was found in P. nigra, P. maximowiczii, and $P$. trichocarpa. The terpenoid with the highest content was sitostenone in all cases, while it was absent in wood of $P$. tremula and P. alba. Other significant compounds were tremulone, $\gamma$-sitosterol, and stigmastanol, each detected in wood of four species.

The obtained results allow for the study on the effect of extractives on the activity of hydrolytic enzymes and are an attempt to correlate with the content of individual substancesidentified.

Author Contributions: Conceptualization A.R., J.Z.; methodology D.S., A.R.; formal analysis D.S., A.R.; investigation D.S., A.R.; data curation A.R., D.S., J.Z.; writing一original draft preparation D.S., A.R.; writing-review and editing P.K., D.S.; visualization P.K., A.R.; supervision J.Z. and P.K. All authors have read and agreed to the published version of the manuscript.

Funding: This research was funded by National Centre of Research and Development in project: BIOSTRATEG2/298241/10/NCBR/2016 "Intelligent systems for breeding and cultivation of wheat, maize and poplar for optimized biomass production, biofuels and modified wood".

Institutional Review Board Statement: Not applicable.

Informed Consent Statement: Not applicable.

Data Availability Statement: Not applicable.

Conflicts of Interest: The authors declare no conflict of interest.

\section{References}

1. Ma, Q.; Lebedys, A. Markets, Trends and Outlook. In Poplars and Willows Trees for Society and the Environment; Isebrands, J.G., Richardson, J., Eds.; The Food and Agriculture Organization of the United Nations and CABI: Ottawa, ON, Canada, $2014 ;$ p. 575.

2. Mirek, Z.; Piękoś-Mirkowa, H.; Zając, A.; Zając, M. Krytyczna Lista Roślin Naczyniowych Polski [Flowering Plants and Pteridophytes of Poland: A Checklist]; Instytut Botaniki PAN im. Władysława Szafera w Krakowie: Cracow, Poland, 2002; ISBN 83-85444-83-1.

3. Niemczyk, M.; Wojda, T.; Kaliszewski, A. Biomass productivity of selected poplar (Populus spp.) cultivars in short rotations in northern Poland. N. Z. J. For. Sci. 2016, 46, 22. [CrossRef]

4. West, P.W. Growing Plantation Forests, 2nd ed.; Springer International Publishing: Berlin, Germany, 2014. [CrossRef]

5. Lewandowska, A.; Radomski, A.; Marchwicka, M.; Szadkowska, D.; Archanowicz, E.; Szadkowski, J.; Gawron, J.; Zielenkiewicz, T.; Kłosińska, T.; Zawadzki, J. Study on products of enzymatic hydrolysis of pulp from poplar wood (Populus alba L.). Przem. Chem. 2015, 94, 1134-1137. [CrossRef]

6. Directive 2009/28/EC of the European Parliament and of the Council of 23 April 2009 on the Promotion of the Use of Energy from Renewable Sources and Amending and Subsequently Repealing Directives 2001/77/EC and 2003/30/EC. Available online: https:/ / eur-lex.europa.eu/legal-content/EN/ALL/?uri=celex:32009L0028 (accessed on 28 March 2021). 
7. Directive (EU) 2015/1513 of the European Parliament and of the Council of 9 September 2015 Amending Directive $98 / 70 / E C$ Relating to the Quality of Petrol and Diesel Fuels and Amending Directive 2009/28/EC on the Promotion of the Use of Energy from Renewable Sources. Available online: https://eur-lex.europa.eu/legal-content/EN/TXT/PDF/?uri=CELEX: 32015L1513\&from $=$ ro (accessed on 27 March 2021).

8. Balat, M.; Balat, H.; Öz, C. Progress in bioethanol processing. Prog. Energy Combust. Sci. 2008, 34, 551-573. [CrossRef]

9. Leja, K.; Lewandowicz, G.; Grajek, W. Produkcja bioetanolu z surowców celulozowych. Biotechnologia 2009, 4, 88-101.

10. Taubman, J. Węiel I Alternatywne Źródła Energii, Prognozy na Przyszłość; PWN: Warszawa, Poland, 2011.

11. Belt, T.; Mollerup, F.; Hänninen, T.; Rautkari, L. Inhibitory effects of Scots pine heartwood extractives on enzymatic holocellulose hydrolysis by wood decaying fungi. Int. Biodeterior. Biodegrad. 2018, 132, 150-156. [CrossRef]

12. Kim, Y.; Ximenes, E.; Mosier, N.S.; Ladisch, M.R. Soluble inhibitors/deactivators of cellulase enzymes from lignocellulosic biomass. Enzym. Microb. Technol. 2011, 48, 408-415. [CrossRef]

13. Jönsson, L.J.; Martín, C. Pretreatment of lignocellulose: Formation of inhibitory by-products and strategies for minimizing their effects. Bioresour. Technol. 2016, 199, 103-112. [CrossRef]

14. Ralph, J.; Brunow, G.; Harris, P.; Dixon, R.A.; Schatz, P.F.; Boerjan, W. Lignification: Are lignins biosynthesized via simple combinatorial chemistry or via proteinaceous control and template replication? In Recent Advances in Polyphenols Research; Daayf, F., El Hadrami, A., Adam, L., Ballance, G.M., Eds.; Wiley-Blackwell: Oxford, UK, 2008; pp. 36-66. [CrossRef]

15. Rowell, R.M.; Pettersen, R.; Han, J.S.; Rowell, J.S.; Tshabalala, M.A. Cell Wall Chemistry. In Handbook of Wood Chemistry and Wood Composites; Rowell, R.M., Ed.; CRC Press: Boca Raton, FL, USA, 2005; Volume 3, pp. 35-74.

16. Koshijima, T.; Watanabe, T. Association between lignin and carbohydrates in wood and other plant tissues. In Springer Series in Wood Science; Timell, T.E., Ed.; Springer: New York, NY, USA, 2003; p. 329. [CrossRef]

17. Walker, L.P.; Wilson, D.B. Enzymatic hydrolysis of cellulose: An overiew. Bioresour. Technol. 1991, 36, 3-14. [CrossRef]

18. Bockel, S.; Mayer, I.; Konnerth, J.; Harling, S.; Niemz, P.; Swaboda, C.; Beyer, M.; Bieri, N.; Weiland, G.; Pichelin, F. The role of wood extractives in structural hardwood bonding and their influence on different adhesive systems. Int. J. Adhes. Adhes. 2019, 91, 43-53. [CrossRef]

19. Nascimento, M.S.; Santana, A.L.B.D.; Maranhão, C.; Oliveira, L.S.; Bieber, L. Phenolic Extractives and Natural Resistance of Wood; Biodegradation-Life of Science: Rijeka, Croatia, 2013. [CrossRef]

20. Frankó, B.; Carlqvist, K.; Galbe, M.; Lidén, G.; Wallberg, O. Removal of Water-Soluble Extractives Improves the Enzymatic Digestibility of Steam-Pretreated Softwood Barks. Appl. Biochem. Biotechnol. 2018, 184, 599-615. [CrossRef]

21. Leskinen, Y.; Salas, C.; Kelley, S.; Argyropoulos, D. Wood Extractives Promote Cellulase Activity on Cellulosic Substrates. Biomacromolecules 2015, 16, 3326-3334. [CrossRef]

22. Taylor, A.M.; Gartner, B.L.; Morrell, J.J. Heartwood Formation and natural durability-A review. Wood Fiber Sci. 2002, 34, 587-611.

23. Cantarella, M.; Cantarella, L.; Gallifuoco, A.; Spera, A.; Alfani, F. Effect of inhibitors released during steam-explosion treatment of poplar wood on subsequent enzymatic hydrolysis and SSF. Biotechnol. Prog. 2004, 20, 200-206. [CrossRef] [PubMed]

24. EN 13556:2003Round and Sawn Timber-Nomenclature of Timbers Used in Europe; European Committee for Standardization: Brussels, Belgium, 2003.

25. Antczak, A.; Radomski, A.; Zawadzki, J. Benzene substitution in wood analysis. Ann. Wars. Agric. Univ. For. Wood Technol. 2006, $58,15-19$.

26. Hansen, C.M. The Three Dimensional Solubility Parameter-Key to Paint Component Affinities: III. Independent Calculations of the Parameter Components. J. Paint Technol. 1967, 39, 511.

27. Pettersen, R.C. The chemical composition of wood. In The Chemistry of Solid Wood; Rowell, R.M., Ed.; American Chemical Society: Washington, WA, USA, 1984; Volume 2, pp. 57-126.

28. Prosiński, S. Chemia Drewna; PWRiL: Warszawa, Poland, 1984. (In Polish)

29. Kärki, T.; Väätäinen, J. Extractive Content of European Aspen (Populustremula) Wood after high-temperature Drying. Balt. For. 2004, 10, 39-45.

30. Krutul, D.; Antczak, A.; Radomski, A.; Drożdżek, M.; Kłosińska, T.; Zawadzki, J. The chemical composition of poplar wood in relation to the species and the age of trees. Ann. Wars. Univ. Life Sci. SGGW For. Wood Technol. 2019, 107, 131-138. [CrossRef]

31. Xu, J.; Zhang, Y.; Shen, Y.; Li, C.; Wang, Y.; Ma, Z.; Sun, W. New Perspective on Wood Thermal Modification: Relevance between the Evolution of Chemical Structure and Physical-Mechanical Properties, and Online Analysis of Release of VOCs. Polymers 2019, 11, 1145. [CrossRef]

32. Lustre, A.O.; Issenberg, P. Volatile components of hardwood sawdust smoke. Components of phenolic fraction. J. Agric. Food Chem. 1969, 17, 1387-1393. [CrossRef]

33. Knowles, M.E.; Gilbert, J.; McWeeny, D.J. Phenols in smoked cured meats. Phenolic composition of commercial liquid smoke preparations and derived bacon. J. Sci. Food Agric. 1975, 26, 189-196. [CrossRef]

34. Toraman, H.E.; Vanholme, R.; Borén, E.; Vanwonterghem, Y.; Djokic, M.R.; Yildiz, G.; Ronsse, F.; Prins, W.; Boerjan, W.; Van Geem, K.M.; et al. Potential of genetically engineered hybrid poplar for pyrolytic production of bio-based phenolic compounds. Bioresour. Technol. 2016, 207, 229-236. [CrossRef] [PubMed]

35. SriBala, G.; Toraman, H.E.; Symoens, S.; Déjardin, A.; Pilate, G.; Boerjan, W.; Ronsse, F.; Van Geem, K.M.; Marin, G.B. Analytical Py-GC/MS of Genetically Modified Poplar for the Increased Production of Bio-aromatics. Comput. Struct. Biotechnol. J. 2019, 17, 599-610. [CrossRef] [PubMed] 
36. Zarzyński, P. Identyfikacja i analiza ilościowa substancji o charakterze fenolowym naturalnie występujacych w drewnie wybranych gatunków drzew europejskich i egzotycznych. Leśne Pr. Badaw. (For. Res. Pap.) 2009, 70, 27-39. [CrossRef]

37. Fengel, D.; Wegener, G. Wood Chemistry Ultrastructure Reactions; Chapter 2, Structure and Ultrastructure; Walter de Gruyter: Berlin, Germany, 2003.

38. Yan, L.; Zhang, L.; Yang, B. Enhancement of total sugar and lignin yields through dissolution of poplar wood by hot water and dilute acid flowthrough pretreatment. Biotechnol. Biofuels 2014, 7, 76-80. [CrossRef] [PubMed]

39. Chen, J.; Yuan, Z.; Zanuso, E.; Trajano, H.L. Response of Biomass Species to Hydrothermal Pretreatment. In Hydrothermal Processing in Biorefineries; Ruiz, H., Hedegaard Thomsen, M., Trajano, H.L., Eds.; Springer: Cham, Switzerland, 2017 ; pp. 95-140. [CrossRef]

40. Li, Y.; Qi, B.; Wan, Y. Inhibitory effect of vanillin on cellulase activity in hydrolysis of cellulosic biomass. Bioresour. Technol. 2014, 167, 324-330. [CrossRef]

41. Ando, S.; Arai, I.; Kiyoto, K.; Hanai, S. Identification of aromatic monomers in steam-exploded poplar and their influences on ethanol fermentation by Saccharomyces cerevisiae. J. Ferment. Technol. 1986, 64, 567-570. [CrossRef]

42. Kačík, F.; Ďurkovič, J.; Kačíková, D. Chemical Profiles of Wood Components of Poplar Clones for Their Energy Utilization. Energies 2012, 5, 5243-5256. [CrossRef]

43. Lewis, R.J. Sax's Dangerous Properties of Industrial Materials, 9th ed.; Van Nostrand Reinhold: New York, NY, USA, $1996 ;$ p. 2897.

44. Zhang, B.; Cai, J.; Duan, C.Q.; Reeves, M.J.; He, F. A review of polyphenolics in oak woods. Int. J. Mol. Sci. 2015, 16, 6978-7014. [CrossRef]

45. Luo, C.; Brink, D.L.; Blanch, H.W. Identification of potential fermentation inhibitors in conversion of hybrid poplar hydrolyzate to ethanol. Biomass Bioenergy 2002, 22, 125-138. [CrossRef]

46. Charrouf, Z.; Guillaume, D. Phenols and Polyphenols from Argania spinosa. Am. J. Food Technol. 2007, 2, 679-683. [CrossRef]

47. Creighton, R.H.J.; McCarthy, J.L.; Hibbert, H. Aromatic Aldehydes from Spruce and Maple Woods. J. Am. Chem. Soc. 1941, 63, 312. [CrossRef]

48. Moure, A.; Garrote, G.; Domínguez, H. Effect of Hydrothermal Pretreatment on Lignin and Antioxidant Activity. In Hydrothermal Processing in Biorefineries; Ruiz, H., Hedegaard Thomsen, M., Trajano, H.L., Eds.; Springer: Cham, Switzerland, 2017; pp. 5-45. [CrossRef]

49. Baucher, M.; Chabbert, B.; Van Doorsselaere, J.; Pilate, G.; Cornu, D.; Petit-Conil, M.; Monties, B.; Van Montagu, M.; Inzé, D.; Jouanin, L.; et al. Higher Extractability of Lignin in Poplar (PopulusTremula x P. Alba) by Reducing Cinnamyl Alcohol Dehydrogenase Activity. In Somatic Cell Genetics and Molecular Genetics of Trees; Ahuja, M.R., Boerjan, W., Neale, D.B., Eds.; Forestry Sciences; Springer: Dordrecht, The Netherlands, 1996; Volume 49.

50. Boerjan, W.; Baucher, M.; Chabbert, B.; Petit-Conil, M.; Leplé, J.-C.; Pilate, G.; Cornu, D.; Monties, B.; Inzé, D.; Van Doorsselaere, J.; et al. Genetic modification of lignin biosynthesis in quaking aspen and poplar. In Micropropagation, Genetic Engineering, and Molecular Biology of Populous; Klopfenstein, N.B., Chun, Y.W., Kim, M.-S., Ahuja, M.R., Eds.; General Technical Report RM-GTR-297; USDA Forest Service: Fort Collins, CO, USA, 1997; pp. 193-205. [CrossRef]

51. Meyer, H.J.; Norris, D.M. Vanillin and Syringaldehyde as Attractants for Scolytusmultistriatus (Coleoptera: Scolytidae). Ann. Entomol. Soc. Am. 1967, 60, 858-859. [CrossRef]

52. Iiyama, K.; Lam, T.; Stone, B.A. Covalent Cross-Links in the Cell Wall. Plant Physiol. 1994, 104, 315-320. [CrossRef] [PubMed]

53. Higuchi, P.D. Biochemistry and Molecular Biology of Wood; Springer Series in Wood Science: New York, NY, USA, 1997.

54. Boerjan, W.; Meyermans, H.; Chen, C.; Baucher, M.; Van Doorsselaere, J.; Morreel, K.; Messens, E.; Lapierre, C.; Pollet, B.; Jouanin, L.; et al. Lignin biosynthesis in poplar: Genetic engineering and effects on kraft pulping. Prog. Biotechnol. 2001, 18, 187-194. [CrossRef]

55. Joshi, C.P.; DiFazio, S.P.; Kole, C. Genetics, Genomics and Breeding of Poplar; Science Publishers: Enfield, NH, USA, 2011.

56. Sun, R.C.; Sun, X.F.; Wang, S.Q.; Zhu, W.; Wang, X.Y. Ester and ether linkages between hydroxycinnamic acids and lignins from wheat, rice, rye, and barley straws, maize stems, and fast-growing poplar wood. Ind. Crop. Prod. 2002, 15, 179-188. [CrossRef]

57. Stettler, R.F.; Bradshaw, H.D., Jr.; Heilman, P.E.; Hinckley, T.M. Biology of Populus and its Implications for Management and Conservation; NRC Research Press: Ottawa, ON, Canada, 1996. [CrossRef]

58. Zhang, Z.; Zhang, X.; Peng, W. Measurement Technology on Bioenergy Component of Tobacco Stalk by TD-GC-MS. In 2011 International Conference in Electrics, Proceedings of theCommunication and Automatic Control Proceedings, Chongqing, China, 23-24 June 2011; Chen, R., Ed.; Springer: New York, NY, USA, 2011. [CrossRef]

59. Kakkar, S.; Bais, S. A review on protocatechuic acid and its pharmacological potential. ISRN Pharmacol. 2014, $2014,952943$. [CrossRef] [PubMed]

60. Tanase, C.; Coşarcă, S.; Muntean, D.L. A Critical Review of Phenolic Compounds Extracted from the Bark of Woody Vascular Plants and Their Potential Biological Activity. Molecules 2019, 24, 1182. [CrossRef]

61. Priefert, H.; Rabenhorst, J.; Steinbüchel, A. Molecular characterization of genes of Pseudomonas sp. strain HR199 involved in bioconversion of vanillin to protocatechuate. J. Bacteriol. 1997, 179, 2595-2607. [CrossRef]

62. Seibold, B.; Matthes, M.; Eppink, M.H.; Lingens, F.; Van Berkel, W.J.; Muller, R. 4-Hydroxybenzoate hydroxylase from Pseudomonas sp. CBS3 Purification, characterization, gene cloning, sequence analysis and assignment of structural features determining the coenzyme specificity. Eur. J. Biochem. 1996, 239, 469-478. [CrossRef] 
63. Rowe, J.W. Extractives in Eastern Hardwoods: A Review, General Technical Report (GTR) FPL-18; U.S. Department of Agriculture, Forest Service, Forest Products Laboratory: Madison, WI, USA, 1979.

64. Dixon, R.A.; Srinivasa Reddy, M.S.; Gallego-Giraldo, L. Monolignol Biosynthesis and its Genetic Manipulation: The Good, the Bad, and the Ugly. In Recent Advances in Polyphenol Research; Romani, A., Lattanzio, V., Quideau, S., Eds.; John Wiley \& Sons: Hoboken, NJ, USA, 2014; Volume 4. [CrossRef]

65. Van Acker, R.; Déjardin, A.; Desmet, S.; Hoengenaert, L.; Vanholme, R.; Morreel, K.; Laurans, F.; Kim, H.; Santoro, N.; Foster, C.; et al. Different Routes for Conifer- and Sinapaldehyde and Higher Saccharification upon Deficiency in the Dehydrogenase CAD1. Plant Physiol. 2017, 175, 1018-1039. [CrossRef] [PubMed]

66. Takahashi, L.K. Synchrotron Vacuum-Ultraviolet Postionization Mass Spectrometry with Laser and Ion Probes for Intact Molecular Spatial Mapping of Lignin. Ph.D. Thesis, University of California, Berkeley, CA, USA, 2011.

67. Boerjan, W.; Ralph, J.; Baucher, M. Lignin biosynthesis. Annu. Rev. Plant Biol. 2003, 54, 519-546. [CrossRef]

68. Ximenes, E.; Kima, Y.; Mosier, N.; Diend, B.; Ladisch, M. Inhibition of cellulases by phenols. Enzym. Microb. Technol. 2010, 46, 170-176. [CrossRef]

69. Ximenes, E.; Kim, Y.; Mosier, N.; Dien, B.; Ladisch, M. Deactivation of cellulases by phenols. Enzym. Microb. Technol. 2011, 48, 54-60. [CrossRef] [PubMed]

70. Zheng, Y.; Guo, M.; Zhou, Q.; Liu, H. Effect of lignin degradation product sinapyl alcohol on laccase catalysis during lignin degradation. Ind. Crop. Prod. 2019, 139, 111544. [CrossRef]

71. Ralph, J.; Lu, F. The DFRC Method for Lignin Analysis: Detection and Determination of Acetylated Units in Lignins; 1998 Research Summaries; US Dairy Forage Research Center, University of Wisconsins: Madison, WI, USA, 1999; pp. 41-43. [CrossRef]

72. Grabber, J.H.; Quideau, S.; Ralph, J. P-coumaroylatedsyringyl units in maize lignin: Implications for $\beta$-ether cleavage by thioacidolysis. Phytochemistry 1996, 43, 1189-1194. [CrossRef]

73. Delahaye, P.; Verzele, M. Analysis of gallic, digallic and trigallic acids in tannic acids by high-performance liquid chromatography. J. Chromatogr. A 1983, 265, 363-367. [CrossRef]

74. Sannigrahi, P.; Ragauskas, A.J.; Tuskan, G.A. Poplar as a feedstock for biofuels: A review of compositional characteistics. Biofuels Bioprod. Biorefin. 2010, 4, 209-226. [CrossRef]

75. Wang, W.; Zhuang, X.; Zhenhong, Y.; Qi, W.; Yu, Q.; Wang, Q. Structural Changes of Lignin after Liqiuid Hot Water Pretreatment and ItsEffect on the Enzymatic Hydrolysis. BioMed Res. Int. 2017. [CrossRef]

76. Johnson, C.J. Imbricaric Acid and Perlatolic Acid: Multi-Targeting Anti-Inflammatory Depsides from Cetreliamonachorum. PLoS ONE 2013, 8, e76929. [CrossRef]

77. Raharjo, T.J.; Chang, W.-T.; Choi, Y.C.; Peltenburg-Looman, A.M.G.; Verpoorte, R. Olivetol as product of a polyketide synthase in Cannabis sativa L. Plant Sci. 2004, 166, 381-385. [CrossRef]

78. Kearsey, L.J.; Prandi, N.; Karuppiah, V.; Yan, C.; Leys, D.; Toogood, H.; Takano, E.; Scrutton, N.S. Structure of the Cannabis sativa olivetol-producing enzyme reveals cyclization plasticity in type III polyketide synthases. FEBS J. 2020, 287, 1511-1524. [CrossRef] [PubMed]

79. Gagne, S.J.; Stout, J.M.; Liu, E.; Boubakir, Z.; Clark, S.M.; Page, J.E. Identification of olivetolic acid cyclase from Cannabis sativa reveals a unique catalytic route to plant polyketides. Proc. Natl. Acad. Sci. USA 2012, 109, 12811-12816. [CrossRef]

80. Akhisa, T.; Kokke, W. Naturally occurring sterols and related compounds from plants. In Physiology and Biochemistry of Sterols; Patterson, G.W., Nes, W.D., Eds.; American Oil Chemists' Society: Champaign, IL, USA, 1991; pp. $172-228$.

81. Lea, L.J.; Hepburn, P.A. Safety evaluation of phytosterol-esters. Part 9: Results of a European post-launch monitoring programme. Food Chem. Toxicol. 2006, 44, 1213-1222. [CrossRef] [PubMed]

82. Lehtinen, K.J.; Mattsson, K.; Tana, J.; Engström, C.; Lerche, O.; Hemming, J. Effects of wood-related sterols on the reproduction, egg survival, and offspring of brown trout (Salmo truttalacustris L.). Ecotoxicol. Environ. Saf. 1999, 42, 40-49. [CrossRef]

83. Martin-Creuzburg, D.; Elert, E. Ecological significance of sterols in aquatic food webs. In Lipids in Aquatic Ecosystem; Kainz, M., Brett, M., Arts, M., Eds.; Springer: New York, NY, USA, 2009. [CrossRef]

84. Kerwin, J.L.; Wiens, A.M.; Ericsson, L.H. Identification of fatty acids by electrospray mass spectrometry and tandem mass spectrometry. J. Mass Spectrom. 1996, 31, 184-192. [CrossRef]

85. Kezanka, T.; Pádrová, K.; Sigler, K. Derivatization in Gas Chromatography of Lipids. In Encyclopedia of Lipidomics; Wenk, M., Ed.; Springer: Dordrecht, The Netherlands, 2016. [CrossRef]

86. Knittelfelder, O.L.; Kohlwein, S.D. Derivatization and Gas Chromatography of Fatty Acids from Yeast. Cold Spring Harb. Protoc. 2017, 5, 416-420. [CrossRef]

87. Reid, A.M.; Brougham, C.A.; Fogarty, A.M.; Roche, J.J. An investigation into possible sources of phthalate contamination in the environmental analytical laboratory. Int. J. Environ. Anal. Chem. 2007, 87, 125-133. [CrossRef]

88. Cao, X.-L. Phthalate Esters in Foods: Sources, Occurrence, And Analytical Methods. Compr. Rev. Food Sci. Food Saf. 2010, 9, 21-43. [CrossRef]

89. Guo, Y.; Kannan, K. Challenges encountered in the analysis of phthalate esters in foodstuffs and other biological matrices. Anal. Bioanal. Chem. 2012, 404, 2539-2554. [CrossRef] 